\title{
MUSIC AND SENTIMENT
}

Charles Rosen is an internationally renowned writer and pianist. His numerous books include Beethoven's Piano Sonatas, published by Yale, and he frequently reviews for The New York Review of Books. As a pianist, he has performed and recorded a wide repertoire (notably Bach, Beethoven, Schumann and Debussy) and has been invited by Stravinsky, Pierre Boulez and Elliott Carter to record and give first performances of their works. 



\section{CHARLES ROSEN \\ MUSIC AND SENTIMENT}

YALE UNIVERSITY PRESS

NEW HAVEN AND LONDON 
Published with assistance from the Annie Burr Lewis Fund

\section{Copyright (C) 2010 by Charles Rosen}

First printed in paperback 2011

All rights reserved. This book may not be reproduced in whole or in part, in any form (beyond that copying permitted by Sections 107 and 108 of the U.S, Copyright Law and except by reviewers for the public press), without written permission from the publishers.

For information about this and other Yale University Press publications please contact:

U.S. Office: sales.press@yale.edu yalebooks.com

Europe Office: sales@yaleup.co.uk www.yalebooks.co.uk

Set in Arno Pro by IDSUK (DataConnection) Ltd

Printed in Great Britain by Hobbs The Printers Ltd, Totton, Hampshire

Library of Congress Cataloging-in-Publication Data

Rosen, Charles, 1927-

Music and sentiment / Charles Rosen. p. cm.

Includes index. ISBN 978-0-300-16837-2

1. Music-Philosophy and aesthetics. 2. Music-History and criticism. I. Title. ML3845.R69 2010

$781^{\prime} .11-\mathrm{dc} 22$

ISBN 978-0-300-17803-6 (pbk)

A catalogue record for this book is available from the British Library.

10987654321 
For Kristina Muxfeldt 
